\title{
$\mathrm{Ti}-4 \mathrm{Fe}-7 \mathrm{Al}$ 合金の溶体化塩浴焼入れによる微細組織
}

\author{
井尻政 孝* 奥村 輝* 石川高史* 門脇賢司*＼cjkstart竹元嘉利
}

岡山大学大学院自然科学研究科

J. Japan Inst. Met. Mater. Vol. 80, No. 11 (2016), pp. 691-696

(C) 2016 The Japan Institute of Metals and Materials

\section{Microstructure of Ti-4Fe-7Al Alloy Quenched in a Salt Bath after Solution Treatment}

\author{
Masataka Ijiri*, Akira Okumura*, Takafumi Ishikawa*, Kenji Kadowaki* and Yoshito Takemoto \\ Graduate School of Natural Science and Technology, Okayama University, Okayama 700-8530
}

The $\mathrm{Ti}-4 \mathrm{Fe}-7 \mathrm{Al}$ alloy exhibits some interesting phenomena upon tempering. The noteworthy features are rapid hardening and shape change in a U-shaped specimen with heating, which are caused by the $\beta$ (bcc) $\rightarrow \alpha^{\prime \prime}$ (orthorhombic) transformation at elevated temperature. The transformation behavior on the TTT (time-temperature-transformation) diagram estimated from the age hardening at various temperatures indicated a $\mathrm{C}$-curve with a nose at $450^{\circ} \mathrm{C}$, which means that the transformation occurs through a thermal activation process. However, STEM-EDS analysis of $\alpha^{\prime \prime}$ revealed that the transformation had occurred without atom diffusion. In this study, every solution treatment was carried out at $1050^{\circ} \mathrm{C}$ for 30 min under a vacuum, then the specimen was quenched into a salt bath of $200-550^{\circ} \mathrm{C}$ and held for a certain period prior to water quenching. These treated specimens were compared with the quenched and tempered specimens with respect to the microstructure and the hardening behavior. The hardness of the specimens held at $200-500^{\circ} \mathrm{C}(30 \mathrm{~s})$ increased with increasing holding temperature. The maximum hardness, $610 \mathrm{Hv}$, which was almost the same as that of a tempered specimen, was obtained at around $450^{\circ} \mathrm{C}$. The microstructure of the specimen held at $450^{\circ} \mathrm{C}(30 \mathrm{~s})$ showed a common morphology composed of acicular martensite variants, except for the size. Because the several variants would cancel the transformation strain of each other, no severe unevenness of the surface was generated, unlike the tempered specimen. On the other hand, the hardness of the specimen held at $550^{\circ} \mathrm{C}(30 \mathrm{~s})$ decreased drastically owing to the phase separation to $\alpha+\beta$, and the TiFe precipitates were generated from $\beta$ upon the extension of the holding time.

By the TEM observation of the electropolished thin foil of the specimen held at $450^{\circ} \mathrm{C}(30 \mathrm{~s})$, unreasonable microstructure that was different from the XRD result was obtained. Just after the electropolishing, the SAD patterns showed that the $\alpha^{\prime \prime}-$ structure has a commensurate relation with the $\beta$-lattice. However, $\alpha^{\prime \prime}$ turned spontaneously into an incommensurate relation after one year. On the other hand, TEM observations of the foil prepared by FIB (focused ion beam) were consistent with the XRD result. It was suggested that the hydrogen absorption during electropolishing caused a structural transition of $\alpha^{\prime \prime}$ martensite. [doi:10.2320/jinstmet.J2016032]

(Received May 11, 2016; Accepted July 26, 2016; Published October 25, 2016)

Keywords: $\alpha^{\prime \prime}$-martensite transformation, variant, electropolishing, hydrogen absorption

\section{1. 緒言}

$\mathrm{Ti}-4 \mathrm{Fe}-7 \mathrm{Al}$ 合金 $(4 \mathrm{FeA})^{1,2)}$ をはじめ $\mathrm{Ti}-10 \mathrm{Mo}-$ $7 \mathrm{Al}(10 \mathrm{MoA})^{3)}, \mathrm{Ti}-5 \mathrm{Al}-2 \mathrm{Fe}-3 \mathrm{Mo}(523 \mathrm{AFM})^{4)}$ など幾つか の合金では焼戻しに伴う特異な現象が発現することが明らか になってきた． $4 \mathrm{FeA} や 10 \mathrm{MoA}$ は $\beta(\mathrm{bcc})$ 域での溶体化処理 後の焼入れによって, $\beta$ 相と少量の $\alpha^{\prime \prime}$ (斜方晶) が形成され る. 合金の実質的な $\mathrm{Mo}$ 当量 $\left.{ }^{5,6}\right)\left(\mathrm{Mo}_{\mathrm{effeq}}=\mathrm{Mo}_{\mathrm{eq}}-\mathrm{Al}_{\mathrm{eq}}\right)$ に着 目すると， $4 \mathrm{FeA}, 10 \mathrm{MoA}$ はいずれも $3 \mathrm{Mo}_{\mathrm{effeq}}$ となり， $\beta$ 下 限組成 $\left(10 \mathrm{Mo}_{\mathrm{effeq}}\right)$ よりかなり低く, 2 元系 Ti-Mo では焼入 れによって $\alpha^{\prime}(\mathrm{hcp})$ マルテンサイトが形成される組成であ る.このように $\mathrm{Mo}_{\text {effeq }}$ から予想される焼入れ組織が異なる 合金は他にも報告されている。例えば Ti-16 at \% Nb-4.9 at $\% \mathrm{Sn}^{7,8)}$ は, $3.7 \mathrm{Mo}_{\mathrm{effeq}}$ であるにも関わらず，焼入れで $\beta$ 相が $100 \%$ 残留する.この合金は焼入れ後, $-50^{\circ} \mathrm{C}$ 付近ま

岡山大学大学院院生 (Graduate Student, Okayama University)

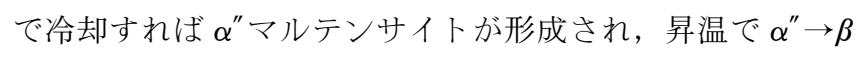
逆変態を引き起こし形状記憶や超弾性が発現するが, 焼入れ 速度によって変態挙動および変形挙動が大きく異なることが 報告されている. Settefrati らは, Ti-5Al-5Mo-5V-3Cr (Ti5553: $5.5 \mathrm{Mo}_{\text {effeq }}$ )の溶体化焼入れで $\beta$ 単相を得ており, その昇温過程で $\alpha^{\prime \prime}$ が形成されることを報告している Abeby-Gautier らも Ti5553 および Ti-5Al-4Mo-4Cr-2Zr$2 \mathrm{Sn}\left(\mathrm{Ti} 17: 1.8 \mathrm{Mo}_{\mathrm{effeq}}\right)$ において溶体化温度から直接, 焼戻 し温度への冷却保持により $\alpha^{\prime \prime} か ゙$ 形成することを報告してい る ${ }^{10)}$. いずれも実質的な Mo 当量と焼入れ組織の乘離が特 異現象をもたらすように思われるが，そのメカニズムについ ては全く解明されていない.

著者らが報告した特異現象は， $450^{\circ} \mathrm{C}$ 付近のごく短時間の 焼戻しで著しく硬化し, 試料表面に激しい凸凹が現れる。 た焼入れ材にひずみを付与して焼戻しを行うと，ひずみ方向 に自発的に形状変化が進展することが挙げられる.この原因 は焼戻しに伴う $\beta \rightarrow \alpha$ 変態が関与しており，わずかなひずみ に応じて優先的な $\alpha^{\prime \prime}$ バリアント選択が生じる．このため変 
態ひずみが複数バリアントによって解消されず，巨視的な変 形を生み出すことを明らかにした ${ }^{11)}$ 。通常の焼入れで形成 される $\alpha^{\prime \prime}$ と，焼戻しで生成される $\alpha^{\prime \prime}$ では，そのサイズが大 きく異なる．前者はミクロンオーダーの針状組織であるため 光学顕微鏡 $(\mathrm{OM})$ で十分に観察できるが, 後者はナノオー ダ一の非常に微細な針状組織であるため, 透過型電子顕微鏡 (TEM) でしか観察できない。また結晶子が微細であるため エックス線回折 $(\mathrm{XRD})$ でのピークが著しくブロードにな り, 解析を困難にする.さらに走查型 TEM (STEM)を用い た $\operatorname{EDS}$ (エネルギー分散型分光) 分析の結果, 焼戻しで形成

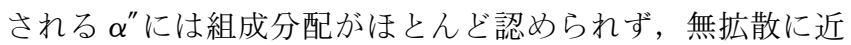
い状態での変態であることがわかっている1,3. にもかかわ らず，4FeAの焼戻しによる硬さの増加量から見積もった $\mathrm{TTT}$ 線図では, $\mathrm{C}$ 型の $\beta \rightarrow \alpha$ 変態曲線を呈することから, 熱活性化過程による変態と考えられる $M_{s}$ 点が C 曲線のように時間依存性を示すのであれば，溶体 化処理から直接 $450^{\circ} \mathrm{C}$ 付近に焼入れ保持しても $\alpha^{\prime \prime}$ は形成さ れると思われる.

本研究では $\mathrm{Ti}-4 \mathrm{Fe}-7 \mathrm{Al}$ 合金を真空中で溶体化処理を行 い, 高温の塩浴に直接焼入れ保持した際の变態挙動および組 織形態について調査を行った.

\section{2. 実 験 方 法}

実験に用いた $\mathrm{Ti}-4 \mathrm{Fe}-7 \mathrm{Al}$ 合金は, $200 \mathrm{~g}$ のインゴットを 熱間鍛造により，約 $60 \mathrm{~mm} \times 65 \mathrm{~mm} \times 3 \mathrm{~mm}$ の板材とした. Table 1 に化学組成を示す. 合金板材から短冊状試料を数枚 切り出し, 冷間圧延により板厚約 $2 \mathrm{~mm}$ の板材とした. さら に小片に小分けし，それぞれ機械研磨および脱脂を行った. 溶体化処理は全て真空中 $1050^{\circ} \mathrm{C}-30 \mathrm{~min}$ で行い, 水水中へ の水冷 $(\mathrm{WQ})$ または $T=200 \sim 550^{\circ} \mathrm{C}$ に設定された塩浴中に 焼入れ $(\mathrm{SQ})$ を行った. $\mathrm{SQ}$ 材は所定の時間 $(t)$ 経過後, 塩浴 から取り出し水冷した $\left(\mathrm{T}^{\circ} \mathrm{C}-\mathrm{SQ}(\mathrm{t})\right.$ 材). 硬さ試験はVickers 硬度計を用いて $2.94 \mathrm{~N}$ の荷重で 7 点測定し平均值を採用し た. XRD 測定は Rigaku 製 Smart Lab を使用し， $45 \mathrm{kV}-$ $200 \mathrm{~mA}$ にて発生した $\mathrm{CuK} \alpha$ 線を用い, 走査角度 $2 \theta: 30$ $90^{\circ}$ の範囲で測定を行った. TEM 観察には Topcon 製 EM002B を使用して, 加速電圧 $160 \mathrm{kV}$ で明視野 $(\mathrm{BF})$, 暗視野 (DF), 制限視野回折 (SAD) 像観察を行った. TEM 試料の 作製には既報 ${ }^{2)}$ と同じ電解研磨法を用い，場合によって FIB (Focuced ion beam) 法も使用した。 STEM を用いた EDS 分析には, Cs コレクタ (球面収差補正) 付の JEOL 製の JEM-2100F を用い, マッピングの際には試料ドリフト補正 を行い測定した。

Table 1 Chemical composition of $\mathrm{Ti}-4 \mathrm{Fe}-7 \mathrm{Al}$ alloy used in this study.

\begin{tabular}{cccc}
\hline $\mathrm{Al}$ & $\mathrm{Fe}$ & $\mathrm{O}$ & $\mathrm{Ti}$ \\
\hline 7.02 & 4.00 & 0.098 & Bal.
\end{tabular}

\section{3. 結果および考察}

$1050^{\circ} \mathrm{C}$ から直接 $450^{\circ} \mathrm{C}$ の塩浴に焼入れした際の試料の温 度変化を Fig. 1 に示す. 測定は $\phi 0.3 \mathrm{~mm} の \mathrm{~K}$ 熱電対を純 $\mathrm{Ti}$ 円板 $(\phi 10 \mathrm{~mm} \times t 1 \mathrm{~mm})$ 表面に溶接し, 真空炉内で $30 \mathrm{~min}$ 加熱後, 炉内に Ar ガスを導入し大気圧に戻ると同時に塩浴 中に焼入れを行った. 試料が $450^{\circ} \mathrm{C}$ になるまでに約 $20 \mathrm{~s}$ を 要していることから, 確実に $450^{\circ} \mathrm{C}$ となる $30 \mathrm{~s}$ を塩浴焼入 れ保持の最短時間とした. なお， $200^{\circ} \mathrm{C}$ および $550^{\circ} \mathrm{C}$ の塩浴 焼入れ保持についても同様な実験を行い, いずれも $20 \mathrm{~s}$ 以 内で温度が一定となることを確認した。

Fig. 2 は $1050^{\circ} \mathrm{C}-30 \mathrm{~min}$ の溶体化処理後, 直接 200 $550^{\circ} \mathrm{C}$ の塩浴に投入し, $30 \mathrm{~s}$ 保持後水冷 $(\mathrm{SQ}(30 \mathrm{~s})$ 材) した $4 \mathrm{FeA}$ 試料の硬さを示す。比較として WQ 材の硬さもプロ ットした. WQ 材では $\beta$ 相がほとんど残留するため $380 \mathrm{Hv}$ であったが，塩浴温度の上昇に伴い硬さは増加し，400〜 $500^{\circ} \mathrm{C}$ に抢いて, ほぼ一定の $610 \mathrm{Hv}$ を示した。この硬さは $450^{\circ} \mathrm{C}-30 \mathrm{~s}$ 焼戻し材 $\left.{ }^{2}\right)$ の值 $(600 \mathrm{Hv})$ とほぼ一致した。しかし 塩浴温度が $550^{\circ} \mathrm{C}$ になる著しい軟化を示した.

Fig. 3 は $450^{\circ} \mathrm{C}-\mathrm{SQ}$ 材の保持時間に伴う硬さ $(\boldsymbol{\nabla})$ の変化と, $\mathrm{WQ}$ 材を $450^{\circ} \mathrm{C}$ で焼戻したときの硬さ $(\triangle)$ を示す 2$) . \mathrm{SQ}$ 材 は 5 枚の試料を同時に $1050^{\circ} \mathrm{C}$ から $450^{\circ} \mathrm{C}$ の塩浴に焼入れし,

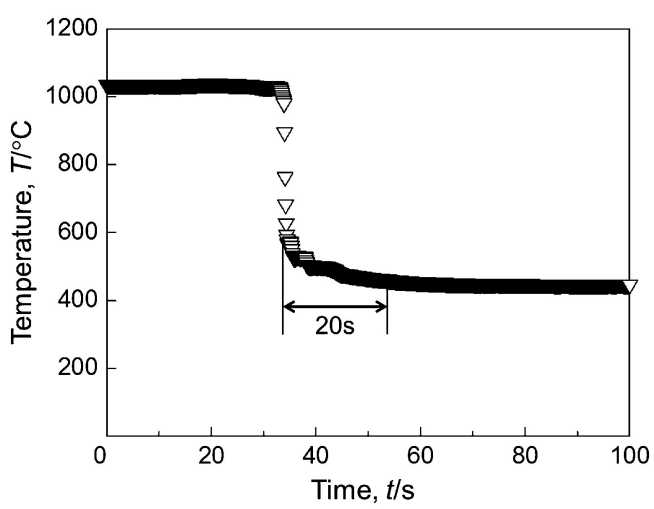

Fig. 1 Typical temperature change of the specimen during quenching from $1050^{\circ} \mathrm{C}$ to $450^{\circ} \mathrm{C}$ in the salt bath. It was confirmed that the temperature became constant within $20 \mathrm{~s}$ as well in the other salt bath temperatures.

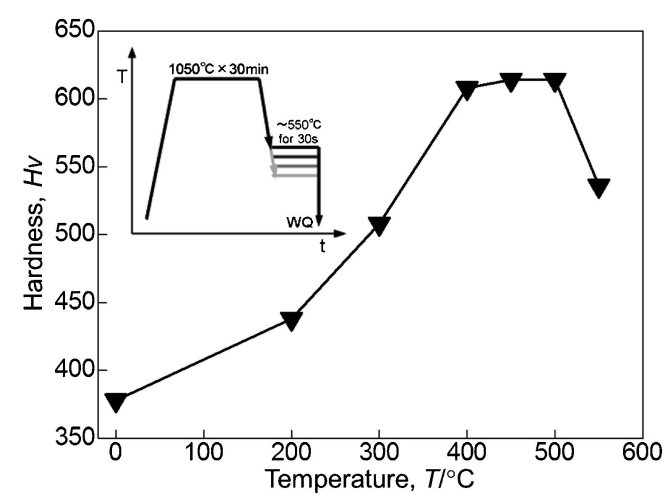

Fig. 2 Hardness of the specimens $\mathrm{T}^{\circ} \mathrm{C}-\mathrm{SQ}(30 \mathrm{~s})$ which were held for $30 \mathrm{~s}$ in the salt bath at various temperatures, followed by the final water quenching. 
$30 \mathrm{~s}, 1.5 \mathrm{~min}, 5 \mathrm{~min}, 10 \mathrm{~min}, 1 \mathrm{~h}$ 後に一枚ずつ取り出し水冷 した． $450^{\circ} \mathrm{C}$ で焼戻しを行った試料では肉眼で認識できるほ どの激しい表面起伏が生じたが1)， $450^{\circ} \mathrm{C}-\mathrm{SQ}$ 材はいずれの 試料も表面起伏は観察されなかった. 硬さは $1.5 \mathrm{~min}$ 保持材 で最大值を示したが，1 h 保持材でもほとんど変化しなかっ た。

Fig. $4(\mathrm{a})$ は $450^{\circ} \mathrm{C}-\mathrm{SQ}(30 \mathrm{~s})$ の光顕組織を示す。電解研磨 抢よび化学腐食(フッ酸：硝酸：水=1: $1: 3 \sim 10$ )を行った が $\beta$ 結晶粒界しか観察できなかった。しかし(b)に示すよう に SEM 観察において, 試料を $70^{\circ}$ 傾斜して観察すると全面 に針状の組織が観察された。

Fig. 5 は代表的な $\mathrm{T}^{\circ} \mathrm{C}-\mathrm{SQ}(\mathrm{t})$ 材の XRD 結果を示す. 塩浴 温度が低い $250^{\circ} \mathrm{C}-\mathrm{SQ}(30 \mathrm{~s})$ は，大部分が $\beta$ 相から構成され るが，わずかに $\alpha^{\prime \prime}$ のピークも認められた。一方，非常に硬 化した $450^{\circ} \mathrm{C}-\mathrm{SQ}(30 \mathrm{~s})$ では，パターンがブロードではある が $\alpha^{\prime \prime}$ 相から構成されていることがわかった． $450^{\circ} \mathrm{C}-\mathrm{SQ}(1$ h) でも構成相は変わらないが， Table 2 に示すように $\alpha^{\prime \prime}$ の 格子定数には变化が認められた。特に斜方晶の度合いを表す 軸比 $\boldsymbol{b} / \boldsymbol{a}$ は， $30 \mathrm{~s}$ 保持材で $1.67 ， 1 \mathrm{~h}$ 保持材では 1.71 であ ったことから，焼戻しの場合 ${ }^{2)}$ と同様に，時間とともに hcp

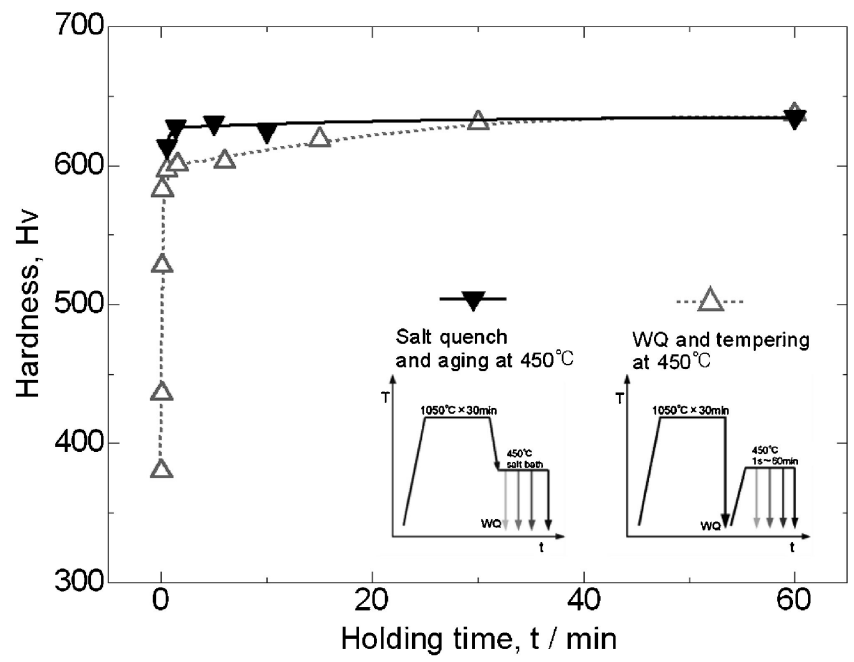

Fig. 3 Hardness evolution as a function of the holding time in the salt bath at $450^{\circ} \mathrm{C}(\boldsymbol{\nabla})$, followed by the final water quenching. Symbols of $(\triangle)^{2)}$ show hardness evolution with isothermal tempering at $450^{\circ} \mathrm{C}$ after the direct water quenching from $1050^{\circ} \mathrm{C}$.
の值 (1.73)に近づくことがわかった。一方， $550^{\circ} \mathrm{C}-\mathrm{SQ}(30$ s) では図には示さないが，ほぼ $\alpha$ 相(hcp)のパターンを示 し，わずかに $\beta$ 相のピークも認められた。しかし $550^{\circ} \mathrm{C}-\mathrm{SQ}$ (1h) まで保持すると， $\beta$ 相のピークは消滅し，代わって TiFeのピークが出現した.

Fig. 6 は軟化を示した $550^{\circ} \mathrm{C}-\mathrm{SQ}$ 材の TEM 観察結果を示 す.（a)は $30 \mathrm{~s}$ 保持材で，針状 $\alpha+\beta$ 組織であった。（b)の 1 $\mathrm{h}$ 保持材では $\alpha$ 相が太く成長して抢り， $\alpha$ 相の周りには 50 $\mathrm{nm}$ 程度の粒子が多数観察された。これらの粒子について STEM-EDS 分析を行った結果，粒子内で Fe が濃化してい ることがわかった。また（b)の SADパターンに拉て $\langle 002\rangle_{\beta}^{*}$ の $1 / 2$ 付近に規則反射が認められること，および XRDの結果からこの粒子は $\mathrm{TiFe}$ であることがわかった. 恐らく $30 \mathrm{~s}$ 保持材では $\alpha$ 相に沿って $\beta$ 相が存在しており， 保持時間の増加に伴って $\beta \rightarrow \alpha+\mathrm{TiFe}$ に分離したものと考え られる. 以上の結果より， $550^{\circ} \mathrm{C}$ 保持では原子拡散によって $\beta \rightarrow \alpha+\beta \rightarrow \alpha+\mathrm{TiFe}$ 変態が進行することが明らかとなった.

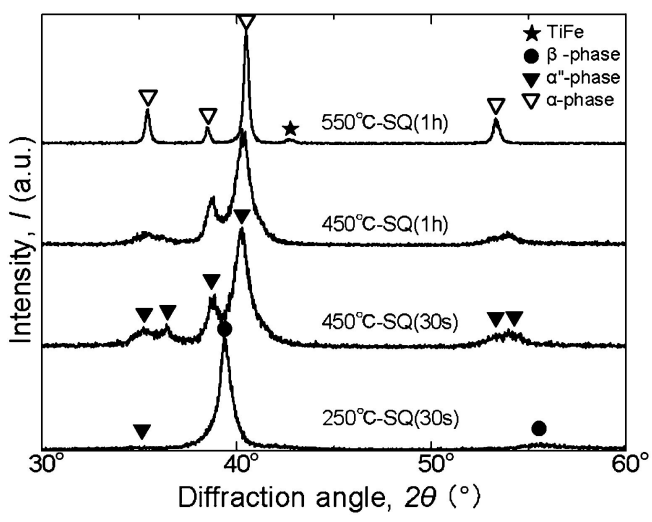

Fig. 5 XRD profiles of specimens after various treatments $\mathrm{T}^{\circ} \mathrm{C}-\mathrm{SQ}(\mathrm{t})$, followed by water quenching.

Table 2 The lattice parameters of $\alpha^{\prime \prime}$-structure of the specimens $450^{\circ} \mathrm{C}-\mathrm{SQ}(30 \mathrm{~s}$ or $1 \mathrm{~h})$.

\begin{tabular}{cllll}
\hline \multirow{2}{*}{ specimen } & \multicolumn{4}{c}{ lattice parameters } \\
\cline { 2 - 5 } & $\boldsymbol{a} / \mathrm{nm}$ & $\boldsymbol{b} / \mathrm{nm}$ & $\boldsymbol{c} / \mathrm{nm}$ & $\boldsymbol{b} / \boldsymbol{a}$ \\
\hline $450^{\circ} \mathrm{C}-\mathrm{SQ}(30 \mathrm{~s})$ & 0.298 & 0.496 & 0.464 & 1.67 \\
$450^{\circ} \mathrm{C}-\mathrm{SQ}(1 \mathrm{~h})$ & 0.296 & 0.505 & 0.462 & 1.71 \\
\hline
\end{tabular}

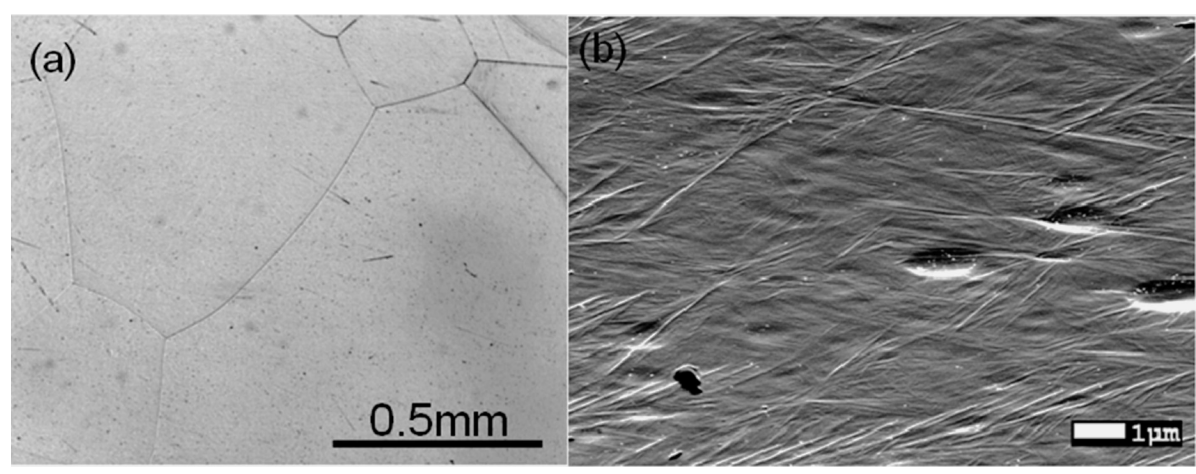

Fig. 4 Microstructure of the specimen $450^{\circ} \mathrm{C}-(30 \mathrm{~s})$. (a) $\mathrm{OM}$ image shows only $\beta$ grain boundaries. (b) SEM image with sample tilt of $70^{\circ}$ shows martensitic acicular structure. 


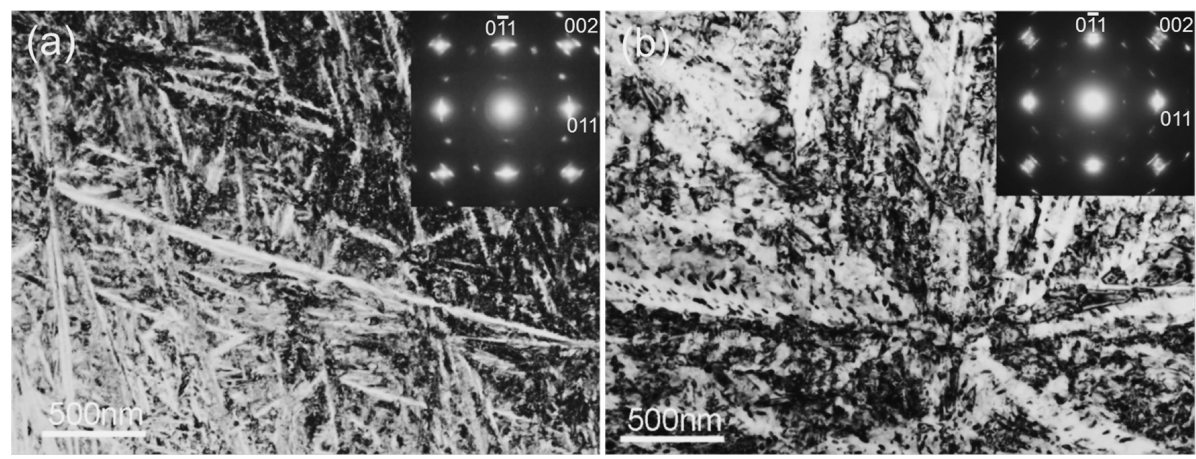

Fig. 6 TEM micrographs and SAD patterns in the specimens (a) $550^{\circ} \mathrm{C}-\mathrm{SQ}(30 \mathrm{~s})$ and (b) $550^{\circ} \mathrm{C}-\mathrm{SQ}(1 \mathrm{~h})$. Both beams $/ /[100]_{\beta}$. Coarse acicular products are $\alpha$-phase. Small granular particles visible beside the $\alpha$-products in (b) are TiFe precipitates.
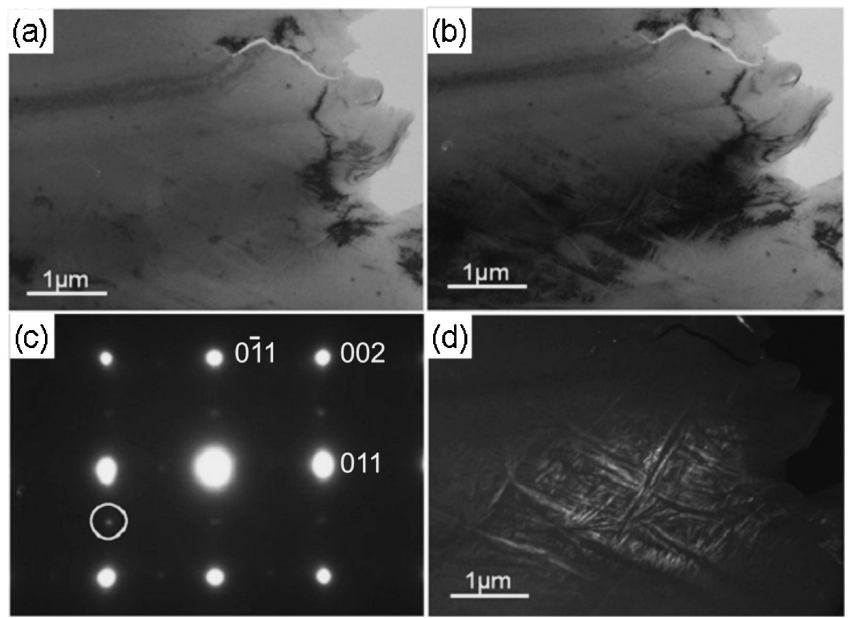

Fig. 7 TEM micrographs of $450^{\circ} \mathrm{C}-\mathrm{SQ}(30 \mathrm{~s})$. The TEM foil was prepared by electropolishing. (a) and (b) are BF images at the same area, but each diffraction condition is a little different. (c) SAD pattern obtained from the dark area in (b). (d) DF image obtained by using the encircled spot in (c).

Fig. 7 は非常に硬化した $450^{\circ} \mathrm{C}-\mathrm{SQ}(30 \mathrm{~s})$ 材の TEM 観察 結果を示す。一見すると $\beta$ 単相組織(a)であり，なぜ $610 \mathrm{Hv}$ もの硬さがあるのか理解できなかったが，回折条件をわずか に変えると，(b)に示すような微細な針状組織が存在してい ることがわかった。(c)は (b)の針状組織から得られた SAD 像で $(100)_{\beta}$ パターンを示す.〈011 㫪の $1 / 2$ に $\alpha^{\prime \prime}$ の反射が認 められる. (d) は SAD 像の○で囲った $\alpha^{\prime \prime} 反$ 射による DF 像 で，微細な針状 $\alpha^{\prime \prime}$ が観察された。 $\alpha^{\prime \prime}$ は複数のバリアントを 伴って形成されており，サイズは非常に小さいが，通常の焼 入れマルテンサイトとよく似た形態を有している。このこと から複数の $\alpha^{\prime \prime}$ バリアントが $\beta \rightarrow \alpha^{\prime \prime}$ に伴う变態ひず 反を解消 するため, 焼戻し材のような激しい表面起伏1)が生じないと 推察される.また，針状組織が非常に微細であることから， $610 \mathrm{Hv}$ もの硬さを引き出していると考えられる. 以上の結 果より溶体化後, $450^{\circ} \mathrm{C}$ の塩浴に焼入れ保持しても, 焼戻し 材々同様に $\beta \rightarrow \alpha^{\prime \prime}$ 変態が生じて著しく硬化する．また，サイ ズは微細であるが複数の $\alpha^{\prime \prime}$ バリアントを伴った一般的な焼 入れマルテンサイト組織を有することがわかった.

$4 \mathrm{FeA}$ 合金は $\beta$ 下限組成である $\mathrm{Ti}-4$ mass $\% \mathrm{Fe}$ に $\mathrm{Al}$ が 7 mass \% も添加されており, 本来, $M_{\mathrm{s}}$ は室温以上にあると思
われるが，等温マルテンサイトのように時間依存性 2 を示す ため, 冷却速度の速い水冷ではマルテンサイト変態が生じ ず，高温の $\beta$ 相が残留する．その後の焼戻しに伴う特異現 象は, 過利凍結空孔が深く関与して抢り, 空孔には $\beta$ 安定 化の働きがあると我々は考えている。つまり水冷で残留した $\beta$ 相には多量の空孔が凍結されているが， $450^{\circ} \mathrm{C}$ で焼戻しを 行うと熱活性により空孔が拡散し, 平衡濃度まで低下しょう とする，試料表面や結晶粒界では空孔が消滅しやすいが，粒 内では空孔が消滅しにくく, 空孔濃度に濃淡(ゆらぎ)が形成 される，粒内の空孔濃度が低下した微小領域では $\beta$ 相の自 由エネルギーは上昇し， $\alpha^{\prime \prime}$ の核生成・成長が生じる。しか し核生成サイトが非常に多く, 空孔濃度の高いウォールによ っても成長が阻まれるため, 結果として微細な $\alpha^{\prime \prime}$ となる. つまり特異現象の時間依存性は, 過剩な空孔が拡散して低い 空孔濃度領域が形成されるまでの時間に起因すると考元られ る.このシナリオによれば，室温でも空孔が消滅すれば $\beta \rightarrow$ $\alpha^{\prime \prime}$ 変態が進行すると考えられる。しかし今のところそのよ うな事実は見つかっていない，これは $4 \mathrm{FeA}$ 合金の拡散係数 が非常に低いため，室温では空孔が移動できないためと考え られる2).ただし， $350^{\circ} \mathrm{C}$ 以上の高温だと，原子拡散を伴っ た $\beta \rightarrow \alpha$ 変態が起こる可能性も十分にある.どちらが作動す るかは，マルテンサイト変態に必要な応力 $\sigma_{\beta \rightarrow \alpha^{\prime \prime}}$ と原子拡散 の駆動力の競合による. 高温に抢ける応力 $\sigma_{\beta \rightarrow \alpha^{\prime \prime}}$ が低い合金 $(4 \mathrm{FeA} や 10 \mathrm{MoA})$ では $\beta \rightarrow \alpha^{\prime \prime}$ 変態が作動できるが， $\sigma_{\beta \rightarrow \alpha^{\prime \prime}}$ が 高い合金 $\left(35 \mathrm{NbA}^{12}\right)$ では，原子拡散を伴った $\beta \rightarrow \alpha$ "変態が 生じると考えられる。いずれの変態が作動しても，形成され るバリアントに偏りがあれば，試料表面の凹凸や，U字曲 げ材の形状変化が発現することには変わりない，また焼戻し では特定の $\alpha^{\prime \prime}$ バリアントが優先的に形成されるのに対し， 本研究で行った溶体化後, 高温保持して水冷すると複数の

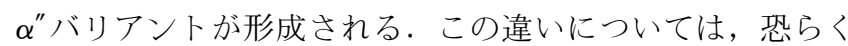

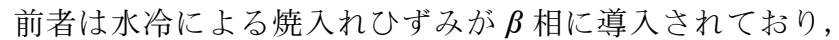
これが焼戻しに抢ける $\beta \rightarrow \alpha$ 変態で特定のバリアント選択を 引き起こしていると考えられる.

Fig. 8 は $450^{\circ} \mathrm{C}-\mathrm{SQ}(30 \mathrm{~s})$ の色々な方位から $\mathrm{SAD}$ を撮影し た結果を示す．(a)〜 (e)の基本反射はいずれも $\beta$ 相として 指数付けでき，点線は $\beta$ 相のパターンを示している． $\alpha^{\prime \prime}$ は $\beta$ 基本反射の $1 / 2$ に出現して打り， $\beta$ 相と整合であることが分 かる.この結果から $\beta$ 相と $\alpha^{\prime \prime}$ の格子定数には $\boldsymbol{a}_{\alpha^{\prime \prime}}=\boldsymbol{a}_{\beta}, \boldsymbol{b}_{\alpha^{\prime \prime}}$ 
$=\sqrt{2} \alpha_{\beta}, \quad \boldsymbol{c}_{\alpha^{\prime \prime}}=\sqrt{2} \alpha_{\beta}$ の関係が成り立ち, $\boldsymbol{b}_{\alpha^{\prime \prime}} / \boldsymbol{a}_{\alpha^{\prime \prime}}=1.41$ になる はずである.しかし，これは Table 2 で示したXRDの結果 $(\boldsymbol{b} / \boldsymbol{a}=1.67)$ とは明らかに矛盾する.

Fig. 9 は Fig. 7, 8 と同一の TEM 試料であるが，室温で 1 年間経過前後の TEM 観察結果を示す。（a）は電解研磨直後 の組織であり， $[011]_{\beta}$ から観察を行った。〈211 炎の $1 / 2$ に $\alpha^{\prime \prime}$ の反射が認められ $\alpha^{\prime \prime}$ は $\beta$ 相と整合な関係にある。(b)はそ の 1 年後に観察した結果を示す。組織的な变化はあまり見 られなかったが，SAD においては明らかに変化しており， $\beta$ の基本反射周り，およびく 211$\rangle_{\beta}^{*}$ の $1 / 2$ 付近に多くの反射が
現れている.この $\mathrm{SAD}$ パターンは XRD の結果とほぼ一致 する。したがって，電解研磨直後 (a)の結果が異常であると 考えられる。

TEM 試料作製における電解研磨の影響を調査するため, $450^{\circ} \mathrm{C}-\mathrm{SQ}(30 \mathrm{~s})$ 材から FIB を用いて TEM 試料をサンプリ ングし，SAD 観察した結果を Fig. 10 に示す。(a) と (b)は $[011]_{\beta}$ および $[111]_{\beta}$ で，それぞれ Fig. $9(\mathrm{a})$ と Fig. 8(b)に 対応する．組織的には電解研磨試料と同じ針状組織であった が，SAD は電解研磨直後のパターン (Fig. $9(\mathrm{a}))$ とは異な り，むしろ電解研磨後 1 年経過したパターン (Fig. 9(b))に
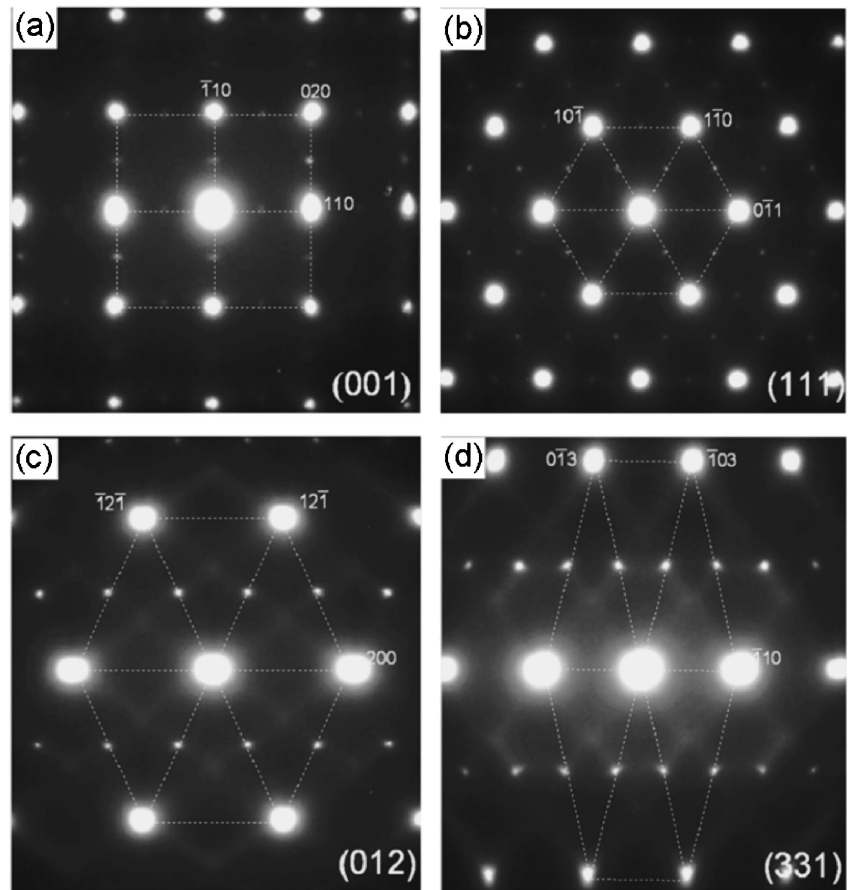

Fig. 8 SAD patterns taken from various orientations of $450^{\circ} \mathrm{C}-\mathrm{SQ}(30 \mathrm{~s})$. Dashed lines show fundamental pattern of $\beta$ phase. Smaller spots are of the $\alpha^{\prime \prime}$-phase showing a commensurate relation with the $\beta$ lattice. However, the $\alpha^{\prime \prime}$-structure corresponding to these patterns is inconsistent with XRD result. The TEM foil was prepared by electropolishing.

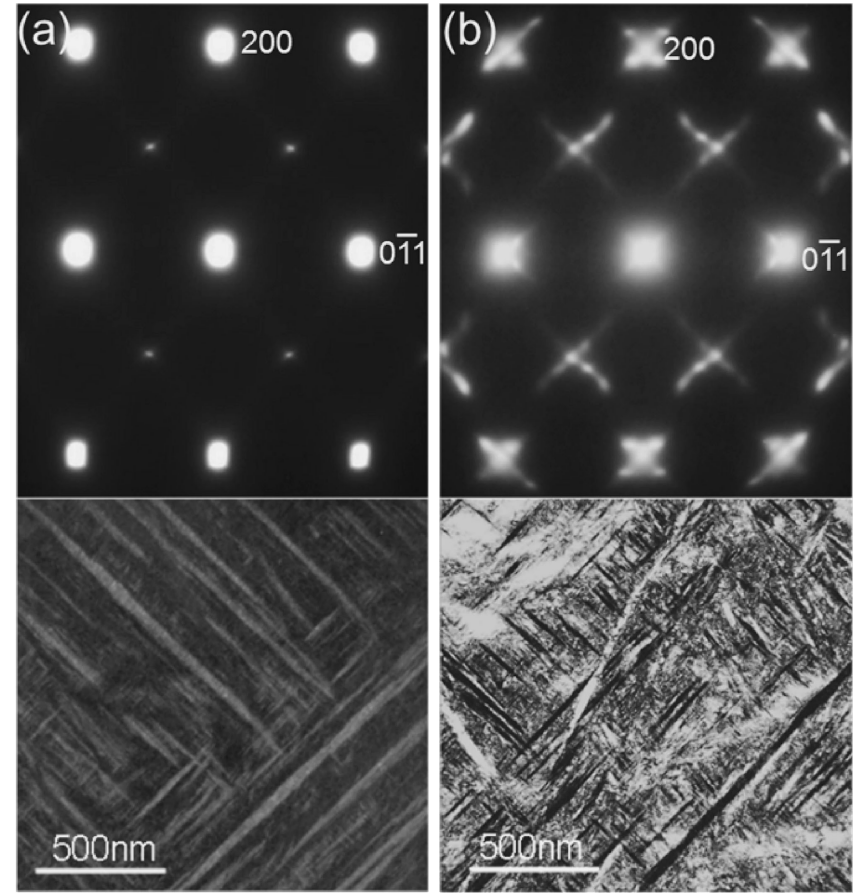

Fig. $9 \mathrm{SAD}$ patterns and TEM micrographs of $450^{\circ} \mathrm{C}-\mathrm{SQ}(30$ s). (a) Observation after TEM foil preparation by an electropolishing. (b) The same foil aged at room temperature for one year. As compared with the SAD pattern (a), the relation between $\beta$ and $\alpha^{\prime \prime}$ lattice became incommensurate one which is consistent with the XRD result, however, the microstructure hardly changed. Both beams $/ /[011]_{\beta}$.
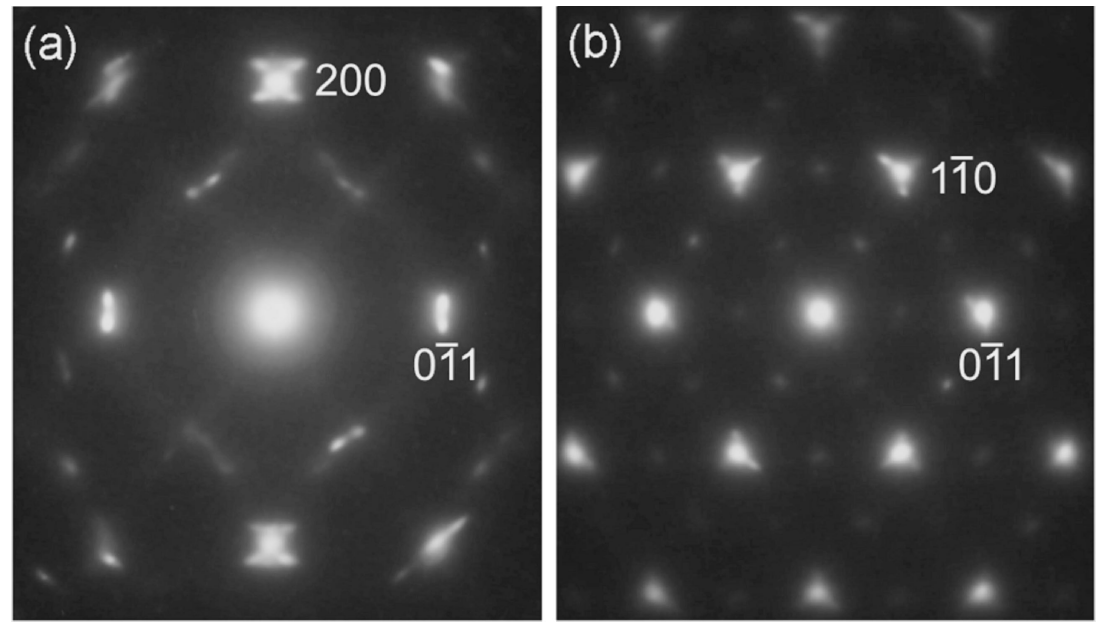

Fig. $10 \mathrm{SAD}$ patterns of $450^{\circ} \mathrm{C}-\mathrm{SQ}(30 \mathrm{~s})$ foil which was prepared by FIB sampling technique. The $\alpha^{\prime \prime}-$ structure corresponding to the patterns is consistent with XRD result. (a) Beam $/ /[011]_{\beta}$, (b) $/ /[111]_{\beta}$. 
近いものであった。したがって，FIBによる TEM 試料の方 が XRD と矛盾しない結果が得られることがわかった。

電解研磨によるアーティファクトは古くから報告13-16)さ れており, 薄膜自発変態や水素の影響が懸念されている. 特 に電解研磨は約 $-40^{\circ} \mathrm{C}$ の低温で行われるため, $\beta$ 相を安定 化させる水素が吸収され, $\alpha^{\prime \prime} \rightarrow \beta$ 逆变態が生じやすいと考え られる. 最近, 電解研磨によって作製した $10 \mathrm{MoA} の \mathrm{TEM}$ 試料でも， $\alpha^{\prime \prime} \rightarrow \beta$ 逆変態が生じていることを報告した ${ }^{3)}$ 。そ の合金の WQ 材は光顕観察では焼入れマルテンサイトが観 察されるものの, TEM 観察ではなかなかそれを確認できな かった. 唯一, 粒界近傍に焼入れマルテンサイトの形態を有 した針状生成物が確認されたが，その構造はbccであり積 層欠陥縞に似た多数の縞が生成物内外に存在するものであっ た. 他にもバンド状の輪郭だけを残した組織も多く観察され たが，これらも多数の縞が存在するだけで，構造はやはり bccであった．これらの現象を統一的に解釈すると, Fig. 8 抢よび Fig. $9(\mathrm{a})$ の $\beta$ と整合した $\alpha$ "は, 電解研磨中に水素が 固溶し， $\alpha^{\prime \prime} \rightarrow \beta$ 逆変態の遷移段階にあると考えられる.この 段階では $\boldsymbol{b} / \boldsymbol{a}$ が $\sqrt{2}$ に一致しているが， $\alpha^{\prime \prime}$ 特有の〈211 $\rangle_{\beta}^{*}$ の $1 / 2$ 反射が観察されることから，(002) $\alpha_{\alpha^{\prime \prime}}$ の shuffling は維持 された状態といえる.さらに水素の固溶量が増加し, shuffling までも解消されると完全な bcc に変態するかもしれな いが今後の課題としたい.

\section{4. 結論}

本研究では $\mathrm{Ti}-4 \mathrm{Fe}-7 \mathrm{Al}$ 合金を真空中で溶体化処理を行い, $200 \sim 550^{\circ} \mathrm{C}$ の塩浴に直接焼入れ保持した際の変態挙動と組 織形態について調査した結果, 以下のことが明らかとなった.

(1) 塩浴焼入れ $30 \mathrm{~s}$ 保持材では温度の上昇とともに硬度 は増加し, $400 \sim 500^{\circ} \mathrm{C}$ で, 焼戻し材の最大硬さと同程度の $610 \mathrm{Hv}$ を示した。しかし $550^{\circ} \mathrm{C}$ では拡散を伴った $\beta \rightarrow \alpha$ 変態 により軟化した。

（2）硬化の原因は非常に微細な針状 $\alpha^{\prime \prime}$ の形成によるが, 焼戻し材と異なり，複数の $\alpha^{\prime \prime}$ バリアントが形成されるた め, 変態ひずみが解消され表面起伏は生じない.
（3）微細な $\alpha^{\prime \prime}$ を有する $450^{\circ} \mathrm{C}-\mathrm{SQ}(30 \mathrm{~s})$ 材を電解研磨で TEM 試料を作製すると， $\beta$ 相と整合した $\alpha^{\prime \prime} に$ 構造が变化す る.しかし 1 年間経過した TEM 試料では不整合な $\alpha^{\prime \prime} に$ 構 造が回復した。一方, FIBで作製すると正常な組織が得ら れることがわかった. 電解研磨では水素の吸収により $\alpha^{\prime \prime} \rightarrow \beta$ 逆変態が生じやすいことを示唆した。

本合金の作製において，新日鐵住金佅の國枝知徳博士およ び東邦チタニウム侏の藤井秀樹博士に便宜を図っていただき ました。また本研究の一部は軽金属奨学会からの補助をいた だいたことを付記して深謝いたします。

\section{文献}

1) Y. Takemoto, M. Ochi, T. Senuma, J. Takada, I. Shimizu and K. Matsugi: J. Japan Inst. Metals 76 (2012) 449-455.

2) Y. Takemoto, K. Fujii, S. Nakastuka and T. Senuma: J. Japan Inst. Met. Mater. 77(2013) 368-374.

3) M. Ijiri and Y. Takemoto: J. Japan Inst. Metals 79(2015) 468473.

4) Y. Takemoto, K. Wada, K. Asakura, T. Senuma, T. Kunieda and H. Fujii: J. Japan Inst. Metals 78 (2014) 434-440.

5) P. J. Bania: JOM. 46 (1994) 16-19.

6) E. W. Collings: Materials Properties Handbook Titanium Alloys (ASM International, 1994) pp. 1-122.

7) E. Takahashi, T. Sakurai, S. Watanabe, N. Masahashi and S. Hanada: Mater. Trans. 43(2002) 2978-2983.

8) Y. Nagai, T. Toyama, Z. Tang, M. Hasegawa, H. Matsumoto and S. Hanada: Scripta Mater. 54 (2006) 1751-1753.

9) A. Settefrati, E. Aeby-Gautier, M. Dehmas, G. Geandier, B. Appolaire, S. Audion and J. Delfosse: Solid State Phenomena 172-174 (2011) 760-765.

10) E. Aeby-Gautier, A. Settefrati, F. Bruneseaux, B. Appolaire, B Denand, M. Dehmas, G. Geandier and P. Boulet: Journal of Alloys and Compounds 577S (2013) S439-S443.

11) Y. Takemoto, M. Ijiri, T. Tanaka and K. Kadowaki: $171^{1 \text { st }}$ CAMP-ISIJ (2016) J008.

12) M. Ijiri, Y. Tomita, T. Ishikawa and Y. Takemoto: J. Japan Inst. Metals 80 (2016) (in press).

13) M. J. Blackburn and J. C. Williams: Trans. Met. Soc. AIME 239 (1967) $287-288$.

14) M. J. Blackburn and J. C. Williams: Trans. Met. Soc. AIME 242 (1968) 2461-2469.

15) R. A. Spurling, C. G. Rhodes and J. C. Williams: Met. Trans. 5 (1974) 2597-2600.

16) R. A. Spurling: Met. Trans. A 6A(1975) 1660-1661. 